\title{
Soil Erosion Thresholds and Alternative States in Northeastern Patagonian Rangelands
}

\author{
Marcelo P. Chartier and César M. Rostagno \\ Authors are Research Scientists, Centro Nacional Patagónico (CONICET), Boulevard Brown s/n, \\ (9120) Puerto Madryn, Chubut, Argentina.
}

\begin{abstract}
In semiarid rangelands, continuous grazing may decrease vegetation cover, accelerating soil erosion and eventually causing a transition to an alternative, degraded state. State-and-transition models invoke process-based explanations of alternative states, but there are few examples that use empirical data on key factors and processes. We used rainfall simulation to determine 1) the relationships between soil surface characteristics and interrill erosion in 3 spatially related plant communities: stable grass with scattered shrubs (GS), degraded grass with scattered shrubs (DGS), and degraded shrub steppes (DSS), and 2) the site conservation threshold (SCT) of this rangeland. We also analyzed the effect of past erosion on soil and vegetation characteristics. In the GS, sediment production and sediment concentration were significantly lower $(p<0.05)$ than in the DGS and the DSS. The main soil protection factors in the GS and in the DGS were perennial grass and litter cover, while in the DSS, gravel cover became the main soil protection factor. The SCT, the point at which the rate of soil erosion increases markedly, corresponded to a plant-and-litter cover close to $90 \%$ and occurred within the DGS. Although this plant community may reverse back to the conserved GS, long-term accelerated erosion may result in enough soil loss to trigger irreversible changes and prompt the transition to the DSS. The threshold underlying this transition would be reached when the A horizon is severely reduced by erosion. Under these conditions, the soil hydrological properties are affected irreversibly, preventing perennial grass establishment. While the GS represents a resource conserving plant community, desirable for both forage production and soil protection, the DSS represents a dysfunctional state with a minimum forage value. The DGS represents an unstable and transitional community that, without management intervention to halt soil erosion, will likely change into the DSS.
\end{abstract}

\section{Resumen}

En los pastizales naturales semiáridos, el pastoreo continuo puede disminuir significativamente la cobertura de la vegetación, acelerar la erosión del suelo y eventualmente causar una transición hacia estados alternativos degradados. Los modelos de estados y transiciones generalmente explican estados alternativos en función de distintos procesos, sin embargo hay pocos ejemplos que usen datos empíricos. Nosotros empleamos lluvia simulada a los fines de determinar 1) las relaciones entre las características superficiales del suelo y la vegetación y la erosión laminar en 3 comunidades vegetales espacialmente relacionadas: una estepa herbácea con arbustos (EH), una estepa herbácea degradada con arbustos (EHD), y una estepa arbustiva degradada (EAD), y 2) el umbral de conservación del sitio (UCS) en éste pastizal. También analizamos el efecto de la erosión histórica sobre las características superficiales del suelo y la vegetación. En la EH la producción y la concentración de sedimentos fueron significativamente más bajos $(p<0.05)$ que en la EHD y la EAD. Los principales factores de protección del suelo en la $\mathrm{EH}$ y la EHD, fueron los pastos perennes y el mantillo, mientras que en la EAD, la cobertura de gravas fue el principal factor de protección del suelo. El UCS, definido como el punto donde la tasa de erosión de suelo aumenta notablemente, se correspondió con una cobertura de pastos perennes y mantillo cercana al 90\% y ocurrió dentro de la EHD. Si bien ésta comunidad puede revertir hacia la $\mathrm{EH}$, la erosión acelerada mantenida durante largo tiempo puede producir una pérdida de suelo tan importante como para provocar cambios irreversibles e iniciar la transición hacia la EAD. El umbral subyacente a la transición se alcanzaría cuando, como consecuencia de la pérdida de suelo, el horizonte A es severamente reducido. Bajo estas condiciones, las propiedades hidrológicas del suelo son afectadas irreversiblemente, limitando el establecimiento de pastos perennes. Mientras que la EH tiene una alta capacidad para conservar los recursos del suelo, representa la comunidad vegetal deseable tanto para la producción de forraje como para la protección del suelo, la EAD representa una comunidad con baja capacidad para conservar los recursos del suelo y bajo valor forrajero. La EHD es una comunidad inestable y transicional que, sin un plan de manejo tendiente a detener la erosión acelerada del suelo, cambiará irreversiblemente a una estepa arbustiva degradada.

Key Words: ecological thresholds, indicators, range conditions, sediment production, state-and-transition model, vegetation dynamics

Research was funded by the Agencia Nacional de Promoción Científica y Tecnológica and CONICET of Argentina.

Correspondence: Marcelo P. Chartier, Centro Nacional Patagónico (CONICET), Boulevard Brown s/n, (9120) Puerto Madryn, Chubut, Argentina. E-mail: mchartier@ cenpat.edu.ar

Manuscript received 22 January 2006; manuscript accepted 15 July 2006.

\section{INTRODUCTION}

Soil erosion is a natural process but the quantity and rate of surface runoff and sediment production may be accelerated by different types of land use or different management practices (Weltz et al. 1998). Soil erosion affects the characteristics and 
the dynamic of many semi-arid plant communities and ultimately may limit the capacity of the land to produce different goods and services. In the long term, erosion may create a mosaic of land surfaces that represents the various state of soil loss or gain (Pickup 1985) and eventually change a functional landscape that efficiently captures, retains, and utilizes water and nutrients into a dysfunctional one that no longer can efficiently capture these resources (Tongway and Ludwig 1996).

In semi-arid rangelands, intense grazing can remove drought-tolerant, highly palatable grasses, which can facilitate the increase of shrub cover (shrub encroachment) and soil degradation (Schlesinger et al. 1990; Parizek et al. 2002). This often leads to the development of alternative stable states. According to Didham and Watts (2005) alternative stable states have been detected mainly in systems that were historically subject to moderate or extreme abiotic regimes. A principal thesis of alternative state models is that the system can shift abruptly between two or more states (Suding et al. 2004). Positive feedback has been proposed as an explanation for dramatic changes in different systems, included arid and semiarid grasslands (Schlesinger et al. 1990; van de Koppel et al. 1997; Davenport et al. 1998).

State-and-transition models (Westoby et al. 1989) hold great potential to aid in understanding rangeland ecosystems' response to natural and/or management-induced disturbances by providing a framework for organizing current understanding of potential ecosystem dynamics (Bestelmeyer et al. 2003; Stringham et al. 2003). Thresholds have become a focal point in the development and application of state-and-transition models. However, the use of thresholds in current state-andtransition models has neither been consistent nor clear on whether thresholds exist between all states, or only a subset of states (Stringham et al. 2003). The initial application of thresholds based on nonreversible transitions in a management time frame (Friedel 1991; Laycock 1991) requires further development for effective interpretation and management of rangeland ecosystems.

Ecological thresholds can be categorized as structural thresholds (based on changes in soil structure, community composition, plant growth form, and spatial distribution of vegetation) and functional thresholds (defined by changes in various ecological processes: e.g., soil erosion, nutrient cycling, and productivity) (Briske et al. 2005). Assessments of functional thresholds are primarily derived from indicators of structural attributes because ecosystem function is difficult to evaluate and quantify (Havstad and Herrick 2003).

State-and-transition models primarily rely on structural thresholds, which are appropriate for vegetation management, but they provide only indirect evidence of ecosystem function. The site conservation threshold represents an attempt to define a single functional threshold based on the type, amount, and pattern of vegetation required to prevent accelerated soil erosion on individual sites (SRM Task Group 1995). The threshold in this case is in the rate of soil erosion. The site conservation threshold and the desired plant community concepts (SRM Task Group 1995) represent an alternative reference point for use in these models that are based on management as well as ecological criteria (Briske et al. 2005).

Although in areas of NE Patagonia some studies have lately recognized the incidence of soil erosion as an important process on permanent vegetation changes (Rostagno and del Valle 1988; Parizek et al. 2002) and others have analyzed the vegetation dynamics in the context of state-and-transition models (see Laycock 1995; Bertiller and Bisigato 1998) functional or structural thresholds associated with a decrease in plant cover have not been analyzed. Grazing rates to prevent accelerated erosion are certainly unknown. In addition, the use of process-based experiments to define the attributes distinguishing states have seldom been attempted (Bestelmeyer et al. 2003). This conceptual approach should enable us to improve our predictive capability relative to erosion thresholds. Hence, it is critical that management of these ecosystems focus on maintaining the soil resource at a level that allows sustainable use (SRM Task Group 1995).

The objectives of this study were 1) to describe the soil and vegetation characteristics in 3 spatially related plant communities, along a degradation gradient in the Punta Ninfas rangelands, and 2) to establish the site conservation threshold using simulated rainfall. With this information we elaborated a state-and-transition model describing the vegetation and soil dynamics within and between states and applied the threshold concept associated with changes in the soil erosion process.

\section{METHODS}

\section{Study Area}

The study area is located in the northeastern of the Chubut province, in the Patagonian region of Argentina, centered at approximately lat $43^{\circ} 00^{\prime} \mathrm{S}$, long $64^{\circ} 30^{\prime} \mathrm{W}$. The climate is arid and temperate. Mean annual precipitation is $258 \mathrm{~mm}(1995-$ 2004). Although most of the rainfall occurs during the cold season (from April to September), heavy rainfall events are more common during the warm season. The mean annual temperature is $12.5^{\circ} \mathrm{C}$ and the mean annual wind velocity at $10 \mathrm{~m}$ above ground level is $4.6 \mathrm{~m} \cdot \mathrm{s}^{-1}$ (Barros 1983).

Dominant soil in the study area is a Xeric Calciargids with Xeric Haplocalcids as the subdominant soil. The Xeric Calciargids is shallow with a loamy sand A horizon 10 to $20 \mathrm{~cm}$ thick, a sandy loam to sandy clay loam Bt horizon 10 to $15 \mathrm{~cm}$ thick, and a calcic horizon Bk 20 to $30 \mathrm{~cm}$ thick. The gravel content in the A horizon varies between $10 \%$ and $15 \%$. A gravelly sand alluvium 50 to $80 \mathrm{~cm}$ thick forms the geological substratum of the soils.

Sheep grazing for wool production is the main use of these rangelands where continuous grazing is practiced extensively $\left(0.3\right.$ sheep $\left.\cdot \mathrm{ha}^{-1}\right)$. The vegetation displays a patchy structure where grass with scattered shrubs and shrub steppe patches alternate over short distances, from 10 to $100 \mathrm{~m}$. Thus, vegetation is a two-phase mosaic dominated by 2 plant functional groups: perennial, cool-season bunch grasses and evergreen shrubs. In the grass with scattered shrub steppe, the perennial grasses flechilla (Stipa tenuis Phil.) and flechilla negra (Piptochaetium napostaense [Speg.] Hackel ap Stuckert) are the dominant species. Neneo (Mulinum spinosum [Cav.] Pers.) and barba de chivo (Prosopidastrum globosum Burk) are the 2 dominant shrubs and quilembai (Chuquiraga avellanedae Lorentz) the subdominant shrub. In the shrub steppe the shrub and dwarf shrub dominant species are quilembai and colapiche (Nassauvia fuegiana [Speg.] Cabrera), respectively. Flechilla 
and other grass species are found in the mounds, associated with shrubs or distributed in small patches or as scattered plants in the inter-shrub area. The dominant soil surface conditions in this plant community are represented by mounds associated with shrubs and the degraded shrub interspaces where a desert pavement has developed as a consequence of partial topsoil stripping. Wind erosion has probably been an important process in molding this mound-intermound pattern. However, at present water erosion seems to be the main geomorphic process as rills and dikes of sediment and litter would indicate. Between the shrub patches and the grass with scattered shrub patches an active eroding zone can be identified.

\section{Methodology}

Within a 2 000-ha paddock, 10 study sites were randomly selected. Each site included patches of stable grass with scattered shrubs (GS), degraded grass with scattered shrubs (DGS), and degraded shrub steppes (DSS). The sample areas were located between 100 and $200 \mathrm{~m}$ of each other to include all the site variability. In each patch, runoff experimental plots $(0.6 \times 1.67 \mathrm{~m})$ were randomly located in shrub interspaces of the different plant communities, where the erosion risk is maximum. Sheet metal frames were dug into the perimeter of the plots to channel the runoff generated by the simulated rainfall. Runoff leaving the lower border of the plots was channeled through a $5-\mathrm{cm}$ diameter pipe connected to 5-liter containers.

Data were collected in the spring of 2003. Simulated rainfall was applied with a full cone, single nozzle rainfall simulator (Rostagno and Garayzar 1995) at an intensity of $100 \mathrm{~mm} \cdot \mathrm{h}^{-1}$, during 30 minutes. In the study area, high intensity rainfall can occur about once per 100 years (Vicenty et al. 1984). We consider that a storm with this extreme characteristic can be useful to discriminate stable from unstable patches and eventually identify the site conservation threshold. Runoff was continuously collected from each plot and was recorded by volume at 5-minute intervals. The sediment production in each plot was obtained by decantation ( 72 hours) in each container. After discarding the over-floating we collected the sediments in $250-\mathrm{ml}$ flask that were dried for 48 hours at $60^{\circ} \mathrm{C}$ and weighed. The sediment concentration was calculated considering total runoff volume.

Prior to simulated rainfall application, runoff plots were sampled along three $1.67-\mathrm{m}$ transects spaced equidistant and oriented parallel to the slope. Distance between perennial plants was determined by the distance between the intercepted perennial plants along each transect. Ground (vegetation, litter, and gravel) and bare soil cover were determined using the point quadrat method (33 points per transect) (Goodall 1952). The size of the largest bare soil patch was also determined in each plot. The depth to the Bt horizon was measured in a pit opened adjacent to each plot. A $130 \mathrm{~cm}^{3}$ soil core (0 to $5 \mathrm{~cm}$ depth) was taken next to each plot for bulk density (Blake 1982) and soil texture (Kettler et al. 2001) determinations.

\section{Data Analysis}

Pearson's correlation coefficients were used to assess the linear association of the variables. The significance of the differences

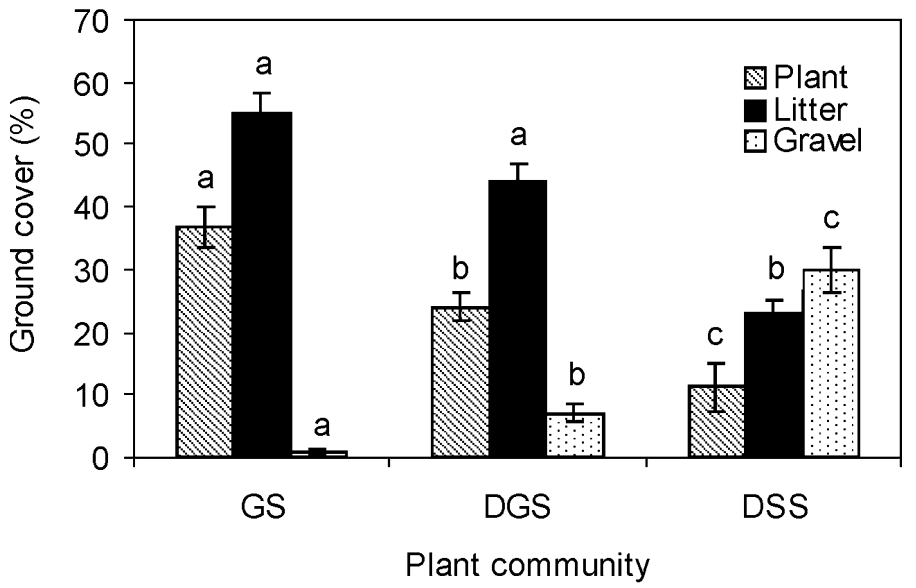

Figure 1. Mean percentage ground cover $( \pm S E)$ for the different plant communities: (GS) grass, (DGS) degraded grass, and (DSS) degraded shrub steppes. Plant community means with the same letters are not significantly different $(P>0.05)$ for plant, litter and gravel cover, respectively.

in sediment production, runoff production and sediment concentration among plant communities (grass, degraded grass, and shrub steppes) were tested by one-way analysis of variance. Mean separation with the Fisher's Protected LSD test was used. Stepwise selection method of the multiple regression analysis was used to identify the independent variables measured that best predicted sediment production using the SPSS package. Already entered variables were tested for removal from the model at each step (probability of F-to-enter $<0.05$, probability of F-to-remove $>0.10)$. Non-linear regression techniques were employed to determine if a threshold of soil stability or a site conservation threshold (SCT) could be determined based on sediment production from runoff plots.

\section{RESULTS}

\section{Surface Characteristics}

Plant and litter cover were significantly higher $(P<0.05)$ in the grass and the degraded grass steppes than in the shrub steppe (Fig. 1). Gravel cover showed an opposite trend with greater values in the DSS. Plant and litter cover were positively correlated $(r=0.42)$, while both were negatively correlated with gravel cover $(r=-0.74$ and -0.75 , respectively). In the DSS where erosion has been more intense than in the other plant communities, we found that the surface gravel concentration increased as the thickness of the remnant $\mathrm{A}$ horizon decreased $(r=-0.61)$.

Soil textural composition was similar among plant communities (Table 1). However, a finer texture was recorded at increasing soil degradation from GS to DSS. The bulk density was significantly higher $(P<0.05)$ in the DSS and the DGS as compared with the GS.

Bare ground cover, distance between perennial plants and largest bare soil patch increased from GS to DSS following the degradation gradient (Fig. 2). Bare soil cover was positively correlated with both largest bare soil patch and distance between perennial plants ( $r=0.55$ and 0.49 , respectively). 
Table 1. Average soil characteristics ( $\pm \mathrm{SE}), 0$ to $5-\mathrm{cm}$ soil depth and $A$ horizon thickness, for different plant communities. Symbols $\left({ }^{*}\right)$ indicate significant statistical differences $(P<0.05)$ among plant community means.

\begin{tabular}{lllr}
\hline & \multicolumn{1}{c}{$\begin{array}{c}\text { Grass } \\
\text { Steppe }\end{array}$} & $\begin{array}{c}\text { Degraded } \\
\text { Grass Steppe }\end{array}$ & $\begin{array}{c}\text { Shrub } \\
\text { Steppe }\end{array}$ \\
\hline Sand $(\%)$ & $71.6(7.5)$ & $69.1(5.4)$ & $66.1(4.5)$ \\
Silt $(\%)$ & $22.0(5.8)$ & $23.9(5.2)$ & $26.9(3.8)$ \\
Clay $(\%)$ & $6.40(3.9)$ & $8.25(2.8)$ & $7.03(4.7)$ \\
Bulk density $\left(\mathrm{Mg} \mathrm{cm}^{-3}\right)$ & $1.22(0.09)^{*}$ & $1.34(0.09)$ & $1.41(0.07)$ \\
A horizon thickness $(\mathrm{cm})$ & $28.0(5.5)^{*}$ & $17.6(12.1)^{*}$ & $5.2(3.4)^{*}$ \\
\hline
\end{tabular}

\section{Sediment Production and Site Conservation Threshold}

Sediment production, runoff generation and sediment concentration were significantly higher $(P<0.05)$ in the DSS than in the GS (Figs. 3A and 3B). However, we found the highest sediment concentration in the DGS with only midrange runoff generation. Sediment production was negatively correlated with perennial plant and litter cover $(r=-0.66$ and -0.64 , respectively) and positively correlated with gravel cover $(r=$ 0.64). Stepwise linear regression analysis, including soil surface characteristics and the A horizon thickness as independent variables, produced the following predictive model for sediment production (SP): SP $\left(\mathrm{g} \cdot \mathrm{m}^{-2}\right)=15.67+0.34$ bare soil cover $(\%)+0.45$ largest bare soil patch $(\mathrm{cm})-0.39$ A horizon thickness $\left.(\mathrm{cm}) ; r^{2}=0.80, P<0.001 ; n=32\right)$.

Nonlinear regression analysis demonstrated a significant sigmoid relationship between sediment production and plantand-litter cover $\left[\mathrm{SP}\left(\mathrm{g} \cdot \mathrm{m}^{-2}\right)=1 /(1 / 60+0.000185 \cdot(1.06733\right.$ exp plant-and-litter cover \%)]; $r^{2}=0.57, P<0.00001, n=30$ ) (Fig. 3C). The sigmoid curve can be described by a logistic equation with parameters for an upper asymptote $K$, a lower asymptote that tends to 0 , and a slope $b$. The curve is symmetrical about an inflection point. Two points of maximum slope change can be defined, above and below which the value of the dependent variable is relatively constant. These points of

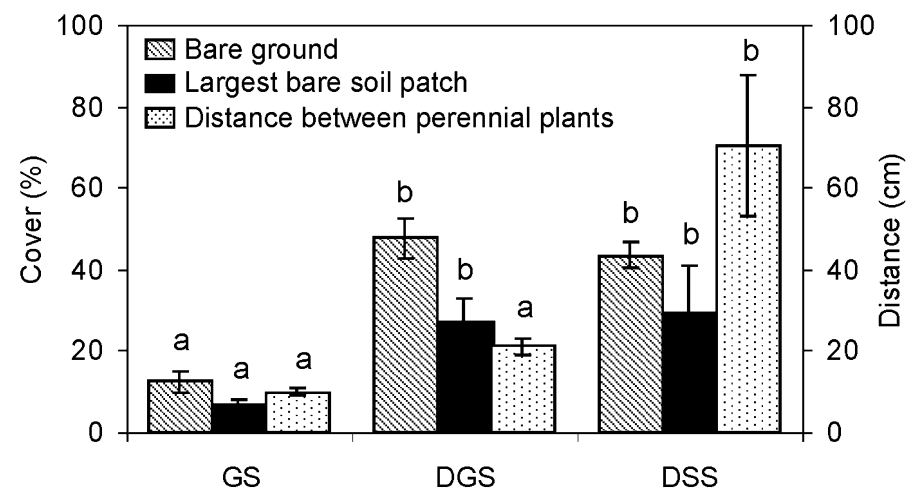

Plant community

Figure 2. Average bare ground cover, diameter of largest bare soil patch and distance between perennial plants $( \pm \mathrm{SE})$ for the different plant communities: (GS) grass, (DGS) degraded grass, and (DSS) degraded shrub steppes. Plant community means with the same letters are not significantly different $(P>0.05)$ for bare ground, largest bare soil patch and distance between perennial plants, respectively.
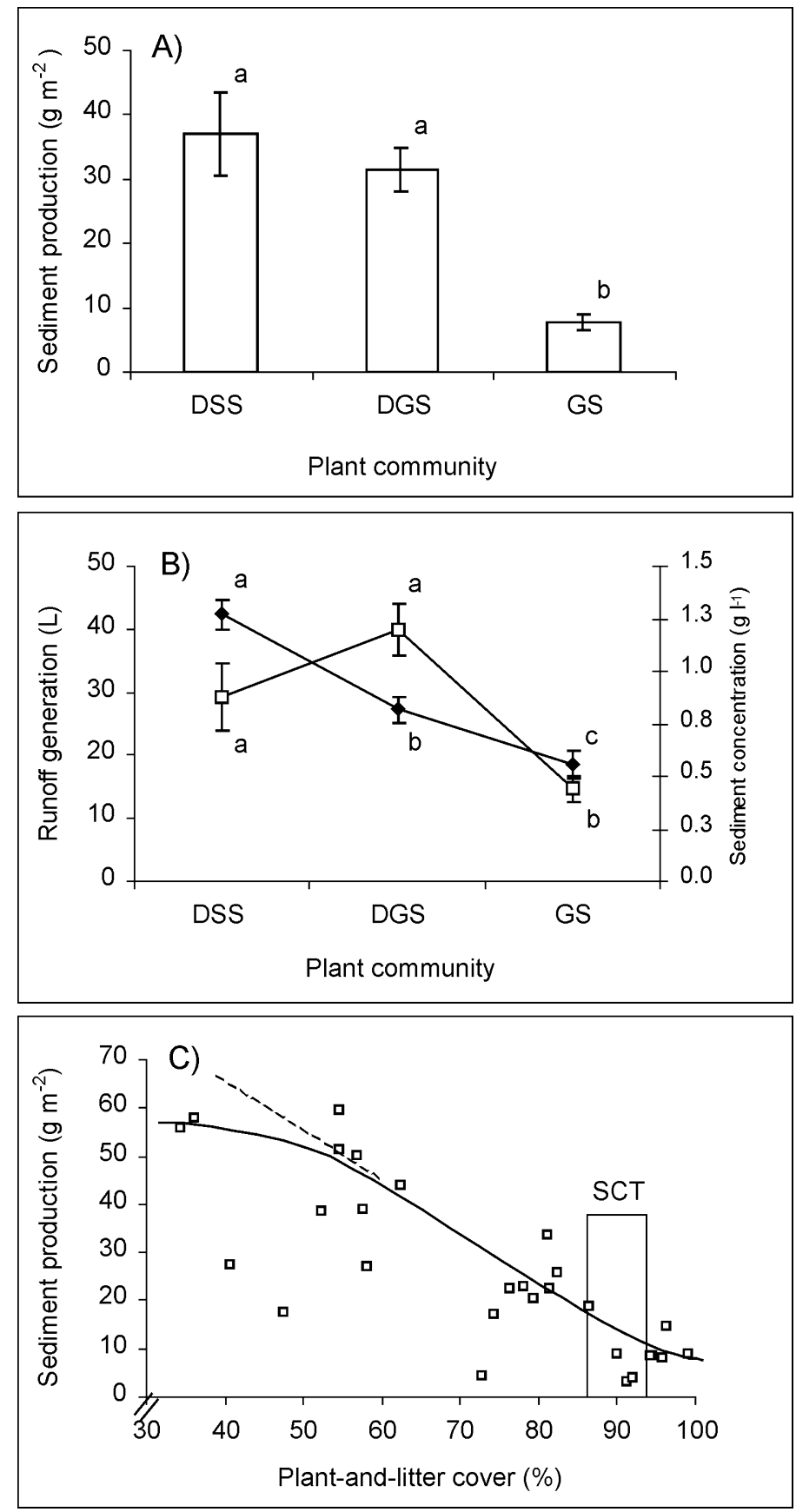

Figure 3. Mean (standard error) sediment production (A), runoff generation (closed symbol) and sediment concentration (open symbol) (B) for grass (GS), degraded grass (DGS) and degraded shrub steppes (DSS), and relationship between sediment production and plant-andlitter cover (C), at Punta Ninfas range site, Patagonia. Site conservation threshold (SCT), the point at which the rate of soil erosion rate increases markedly, corresponds to $90 \%$ of plant-and-litter cover (logistic model $y$ $=1 /(1 / 60+0.000185(1.06733 \exp X)) ; r^{2}=0.57, P<0.00001, n=$ $30)$. Plant community means with the same letters are not significantly different $(P>0.05)$ for sediment production, runoff generation and sediment concentration, respectively. Dashed line would indicate the trend in sediment production if gravels were not present. 
maximum change would represent thresholds in the rate of soil erosion. Between these 2 points sediment production is most sensitive to changes in litter-and-vegetation cover.

The site conservation threshold, considered as the point where erosion rate increases markedly, corresponds to a plantand-litter cover close to $90 \%$ and a sediment production of approximately $15 \mathrm{~g} \cdot \mathrm{m}^{-2}\left(150 \mathrm{~kg} \cdot \mathrm{ha}^{-1}\right)$. The inflection point occurs at a value close to the average $(69.1 \%)$ plant-and-litter cover in the DGS. At this point the sediment production was about $30 \mathrm{~g} \cdot \mathrm{m}^{-2}\left(300 \mathrm{~kg} \cdot \mathrm{ha}^{-1}\right)$. The maximum interrill erosion rate (upper asymptote) corresponded to approximately 60 $\mathrm{g} \cdot \mathrm{m}^{-2}$ in the DSS. The deceleration of the erosion rate as plant-and-litter cover decreases would be related to a significant protection effect of the gravel cover that dominates the intershrub spaces in the DSS.

\section{DISCUSSION}

\section{Soil Surface Characteristics}

In the Punta Ninfas rangelands we recognized a two-phase mosaic, a GS with scattered shrubs and DSS that represent the extremes of the degradation gradient. Soil surface characteristics differ greatly among these plant communities. While in the conserved GS and the DGS the soil protection factors are represented mainly by biotic or biotic-derived factors, plant and litter cover, in the degraded shrub-interspaces areas of the DSS, these protection factors are in part replaced by gravel cover (Fig. 1).

The high bulk density of the degraded A horizon (Table 1) and the poor hydrologic properties of the underlain argillic horizon restrict the capacity to capture the incident rainfall and drastically limit the recovery of the perennial grass cover, mainly in the degraded shrub interspaces of the DSS (Súnico et al. 1996; Parizek et al. 2002). There is substantial evidence that as $C$. avellanedae cover increases the cover of perennial grasses decreases (Beeskow et al. 1995). This is apparent in the area adjacent to its canopy and is probably due to their ability to extract shallow soil moisture from the shrub interspaces. The high erosion rate associated with these areas is clearly indicated by the presence of young individuals of C. avellanedae and Margyricarpus pinnatus (Lam.) Kuntze (a dwarf-shrub) with their roots exposed up to $6 \mathrm{~cm}$ (Rostagno et al. 2004).

The bare ground cover and the size of the bare soil patches showed a marked increment in the DGS as compared with the GS, though no further increment was recorded in the DSS (Fig. 2). In the DSS the greater gravel cover reduced the size of the bare soil patches. The decrease in the perennial grass cover may provide an early indicator of the potential for ecosystem deterioration. A high percentage of perennial grass cover as well as a low distance between perennial plants indicate a high potential for a site to recover from periods of stress, i.e., the ability to re-establish a grass cover over bare patches generated after grazing disturbance or during a period of environmental stress (de Soyza et al. 2000).

\section{Sediment Production and Site Conservation Threshold}

The reduction in perennial grasses and litter cover in both the DGS and the DSS was followed by an increase in sediment production and concentration and runoff production as compared with the GS (Fig. 3A and 3B). The highest sediment concentration recorded in the DSS and the DGS indicates greater sediment removed per runoff unit in these communities compared with the GS. This may be explained in part by the high splash detachment associated with the high bare soil cover in the DGS and the DSS. In addition, the low sediment concentration recorded in the DSS is related to a dilution effect of the high runoff recorded in this plant community. This would suggest that as the DGS change into the DSS the soil infiltration capacity is more severely affected than its erodibility. Sediment concentration may provide a better measure of the erodibility of the different soil surface conditions than sediment production. In the DSS, where the lowest litter and perennial grass cover were recorded, we expected a higher sediment concentration. However, gravels can effectively protect the underlying soil from raindrop impact, the main detachment process in interrill erosion (Poesen et al. 1994) and account for the lower than expected sediment concentration in the DSS.

As the A horizon thickness decreases from GS to DSS the influence in runoff and soil erosion of the underlying restrictive argillic horizon increases. The stepwise multiple regression included the A horizon thickness in the predictive model for sediment production. The argillic horizon restricts vertical water movement which may favor a greater amount of runoff and sediment production as the thickness of the A horizon decreases (Súnico et al. 1996). The higher runoff and sediment losses not only represent a loss in plant available water, but also in organic matter, plant nutrients, and seeds from the upper soil in the bare soil patches (Rostagno et al. 1991; Bertiller and Bisigato 1998). The regression analysis also revealed that sediment production was related to bare ground cover and to the size of the bare ground patches. In the GS, perennial plant cover was high and homogeneously distributed with small bare soil patches. Perennial plants produce a marked microtopography with a high surface water retention capacity in small closed micro-basins that form in the plant interspaces. In this resource-conserving community, the high surface water retention capacity increases the time-to-runoff and the infiltration rate. In contrast, in the DGS and the DSS there is a high interconnection of bare soil patches and the surface water retention capacity is low. According to Weltz et al. (1998) the distribution and connectivity of the bare soil patches are more important than the absolute amount of bare soil in determining potential runoff and soil erosion rates under a given rainfall event. This interconnection networks may explain catastrophic behavior in runoff and erosion (Davenport et al. 1998).

The site conservation threshold (SCT) represents an attempt to define a single functional threshold based on the type, amount, and pattern of vegetation required to prevent accelerated soil erosion on individual sites (SRM Task Group 1995). The threshold in this case is the rate of soil erosion. In our study, perennial grass and litter cover were selected to determine the SCT since both variables are closely associated with sediment production and they are the main soil protection factors in the more conserved plant communities, the GS and DGS (Fig. 1). The site conservation threshold corresponded to a sediment production of about $15 \mathrm{~g} \cdot \mathrm{m}^{-2}\left(150 \mathrm{~kg} \cdot \mathrm{ha}^{-1}\right)$ for a single 30-minute rainfall and occurred when plant-and-litter cover decreased below $90 \%$. Thus, the DGS, providing a soil protection equal to or below of that necessary to prevent 
accelerated erosion, would be considered as an unsatisfactory plant community (SRM Task Group 1995).

Watters et al. (1996) used the Water Erosion Prediction Project (WEPP) model to establish the SCT on a rangeland site in the Chihuahuan semi-desert grassland in southeastern Arizona. The SCT value for this site was determined by solving the fitted relationship between estimated sediment production and site stability rating for a $5 \mathrm{Mg} \cdot \mathrm{ha}^{-1} \cdot \mathrm{yr}^{-1}$. The higher SCT found in the study of Watters et al. (1996) is explained in part by the sharp increase in erosion rate that occurs when rills develop. According to Simanton et al. (1991) rilled plots can produce 3.3 to 3.4 times the average erosion rates compared with non-rilled rangeland areas. The plot length used in our study was not long enough to sample the combined process of rill and interrill erosion since $5 \mathrm{~m}$ is about the minimum slope length that can adequately represent a rill system in a plot (Mutchler et al. 1988). Although rilling generates greater sediment losses and may produce a high off-site environmental impact, interrill erosion selectively removes litter and changes soil surface conditions, a process especially important in the DGS. This may have a great impact in other ecosystem processes such as nutrient and water dynamics that underlay vegetation changes in extensive areas. However, as long as the soil resource is not severely affected, the shift to the DGS could be reversible through management practices and/or natural events that favors the establishment of perennial grasses (e.g. grazing removal or above average precipitation).

\section{Soil Erosion, Thresholds and Transition between Alternative States}

The most effective application of state-and-transition models (Westoby et al. 1989) is to assess the relative benefits and potential risks of various management prescriptions and ecological conditions on subsequent vegetation dynamics (Bestelmeyer et al. 2003). This application is based on recognition that range management can either prevent plant communities from crossing a threshold by maintaining recovery potential of the community (Scheffer et al. 2001), the perennial grass driven ecosystem (Fig. 4A), or accelerate the rate at which an unsatisfactory plant community may cross a threshold to a satisfactory state (Whisenant 1999; Suding et al. 2004).

In our study area, seral stages can be distinguished by differences in the soil erosion rates. In this context, the concept of functional threshold (i.e. the SCT) can be used to distinguish the pathways that flow in both directions between seral phases occurring within the potentially stable state (Figs. 4B and 4C). A reversible transition or pathway (Stringham et al. 2003) occurs between the GS and DGS, and is initiated when the plant-and-litter cover decreases below 90\%. However, given sufficient time, accelerated erosion will result in enough soil loss to prompt the transition to a new alternative stable state.

The second transition involves changes in the soil and occurs when soil physical and chemical properties are altered irreversibly (Friedel 1991). This threshold would separate the transitional DGS from the DSS and could be reached when, as consequence of the historical soil erosion, the A horizon decreases below a given thickness or, in the extreme case, a clayrich horizon is exhumed and affect irreversibly hydrological and ecological processes. Gile and Grossman (1979) describe a similar degradation process for southern New Mexico where the loss of sandy surface horizons on some sandy loam soils has exposed clay-rich strata that no longer support the germination or survival of formerly dominant species.

Bestelmeyer et al. (2003) suggest that to anticipate transitions we need to know the changes in proximate variables underlying threshold responses in vegetation and soils. Probable changes in proximate variables underlying the change in perennial grass cover from DGS to DSS are a reduction in soil moisture and $\mathrm{P}$ and $\mathrm{N}$ availability. Close relations have been quantified between these variables and soil organic matter content (Hudson 1994; Carter 2002). The decrease of perennial grass cover below a certain threshold results in a decrease in litter cover and soil organic matter (Le Houérou 1991). Soil crusting and a dramatic decrease in soil infiltrability generally follow these processes (Rostagno 1989; Pierson et al. 1994) and further increases soil erosion. This positive feedback behavior has been previously proposed for semiarid ecosystems (Davenport et al. 1998). Thus, the loss in productivity set in motion by accelerated soil erosion is a self-sustaining process. Loss of production on eroded soil further degrades its productivity, which, in turn, accelerates soil erosion (Lal 1988). This feedback mechanism maintains or reinforces the degraded plant community and limits reversal to the previous conserved plant community (Scheffer et al. 2001; van de Koppel et al. 2002). Recent conceptual advances in community and landscape ecology indicate that positive plant-soil feedbacks are the dominant cause of catastrophic behavior to further desertification (Schlesinger et al. 1990; van de Koppel et al. 1997; Davenport et al. 1998).

Thus, if soil moisture availability or soil fertility is important for the establishment and survival of the dominant perennial grasses (S. tenuis and P. napostaense), then, across what values of A horizon thickness or other structural changes do threshold responses occur? The observation that perennial grasses are abundant beneath the canopy of C. avellanedae where part of the eroded sediments of the shrub-interspaces areas have accumulated, increasing the thickness and sand content of the original A horizon, support the assumed threshold relationship between the sandy A horizon depth and the perennial grass cover. According to Bestelmeyer et al. (2003), addressing these questions for key grass and shrub species may greatly improve our capacity to provide flexible, predictive models of transitions with management utility that link retrospective data and observations with comparative studies and experiments.

\section{MANAGEMENT IMPLICATIONS}

Perennial grasses are the main forage resources for domestic and wild herbivores and constitute, along with the litter they produce, the main soil protection factor in the original grass with scattered shrub steppes of the Punta Ninfas rangelands. This plant community is not resilient to continuous grazing (i.e. vegetation changes are not continuous and reversible), and in those areas where perennial grasses cover were reduced, soil erosion has increased markedly. The erosion process has further favored the loss of perennial grasses cover. If this process remains uncontrolled, the production potential may be irreversibly lost. 


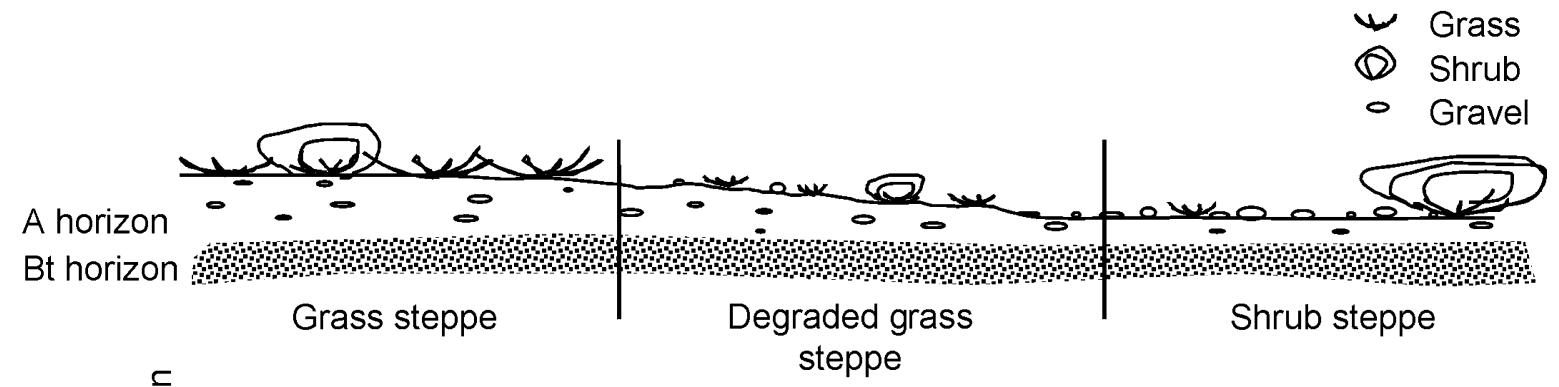

(B)

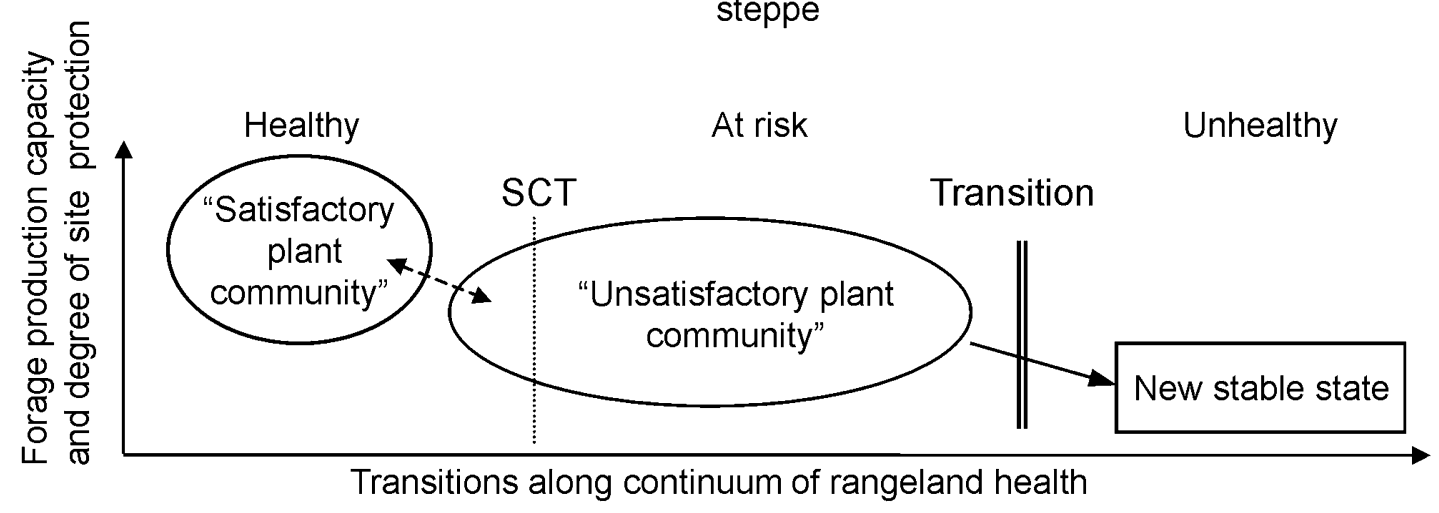

(C)

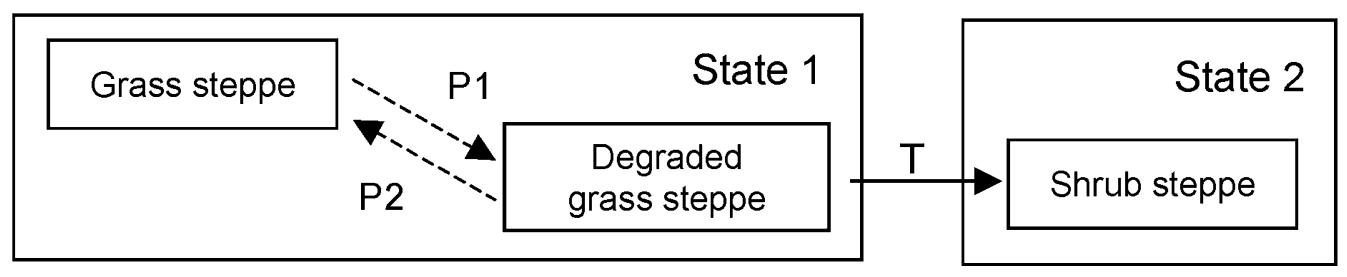

Figure 4. Vegetation dynamics as affected by different soil erosion levels in the Punta Ninfas range, Patagonia: (A) Schematic diagram showing the spatial distribution of different plant communities along a degradation gradient from grass to shrub steppes, associated with soil losses and the thickness A horizon; (B) Conceptual model derived from the NRC (1974) and the Society for Range Management, Task Group on Unity in Concepts and Terminology (1995). The site conservation threshold (SCT) and site conservation rating (SCR) concepts were included. The individual ovals represent plant communities or seral stages that exist within a stable state. The SCT represents a change in the rate of soil erosion between "satisfactory and unsatisfactory" plant communities; and (C) A conceptual state-and-transition model. The small boxes represent plant communities or seral stages of the overall grassland community distinguished by a lower variation in plant community composition and differences in the rates of ecological processes (such as soil erosion and infiltration rates). Dashed arrows between them show that they are joined by community pathways (P1, P2) that flow in both directions (Stringham et al. 2003). These shifts are reversible through management practices and/or natural events (e.g. grazing removal or above average precipitation). The large boxes containing communities are states that are distinguished by differences in structure and the community's ability to maintain control of the ecological processes (e.g. energy capture, nutrient cycling and soil hydrology). Once the threshold is crossed the transition (T) between states (solid arrows) are irreversible on a practical time scale without substantial inputs of energy (Friedel 1991).

Land managers need to know the effect of their management on vegetation and soil functioning, in addition to the effect of other environmental factors beyond their control. The stateand-transition model can improve their capacity to evaluate the costs and consequences of management decisions and to further develop understanding of how these rangeland ecosystems respond to grazing (Bestelmeyer et al. 2003).

In this rangeland, management actions should be directed to keep a high perennial grass and litter cover and stop the feedback mechanisms that ends up in the stable, albeit degraded shrub-dominated state, deleterious to future animal production. The SCT as used in this study is similar to and compatible with the early warning line of the rangeland health concept described by the National Research Council Committee (1994) and separates the healthy and at-risk areas (Fig. 4B). The transition from DGS to DSS is equivalent to the threshold of rangeland health that separates the at-risk and unhealthy areas, and is considered to be not easily reversible. Keeping the grass dominated steppes under the SCT may require a conservative management strategy (i.e. perennial grasses utilization $<30 \%$ as is currently suggested for this rangeland [Elissalde et al. 2002]) and identify the opportunities that favor the pathway from DGS back to GS.

In both the healthy and the at-risk areas, perennial grasses play important ecological roles, and soil infiltrability and resistance to erosion as well as biomass production and nutrient cycling are mainly driven by this growth form. On the contrary, in the DSS, although grasses are still present, their ecological 
roles are subsidiary, and shrubs determine the functioning of this otherwise dysfunctional state that seems to be highly resistant to changes due to grazing management.

\section{CONCLUSIONS AND IMPLICATIONS}

Grazing by removing perennial grasses and pulverizing the surface soil can have a major impact on soil erosion. The primary importance to apply the site conservation threshold concept is to depict the circumstances surrounding vegetation and soil changes on rangeland ecosystems and to use this information to anticipate and intercept persistent transitions in the future (SRM Task Group 1995).

In Punta Ninfas rangelands the increase in soil erosion has been closely associated with the decrease in perennial grass cover and the increase in shrub cover, mainly C. avellanedae in the degraded grass with scattered shrub or degraded shrub steppes. The cumulative effect of accelerated soil erosion has led to irreversible loss of productivity in shallow soils. This suggests that more than one stable state exists and that the vegetation is not resilient to grazing impact. Plant-soil interactions in the perennial grasses driven ecosystem undergo positive feedbacks and the loss of production on eroded soil further degrades its productivity, which, in turn, accelerates soil erosion.

Perennial plant and litter cover jointly may be an earlywarning indicator of the potential for rangeland ecosystem deterioration. Sustainable range management depends primarily on the conservation of the structure and function of the soils and should prevent threshold being reached. Our results suggest that pattern-process relationships can be used to provide a quantitative rationale and indicators for distinguishing transitional and stable states of these rangelands.

\section{ACKNOWLEDGMENTS}

We thank Lina Videla and Alicia Toyos for their assistance in fieldwork. We acknowledge the constructive comments provided by an anonymous reviewer. We are especially grateful to Brandon T. Bestelmeyer for many valuable suggestions that contributed to improve the manuscript.

\section{LITERATURE CITED}

Barros, V. 1983. Atlas del potencial eólico de la Patagonia. Contribución No. 69. Puerto Madryn, Argentina: Centro Nacional Patagónico. 80 p.

Beeskow, A. M., N. O. Elissalde, and C. M. Rostagno. 1995. Ecosystem change associated with grazing intensity on the Punta Ninfas rangelands of Patagonia, Argentina. Journal of Range Management 48:517-522.

BertilleR, M. B., and A. J. Bisigato. 1998. Vegetation dynamics under grazing disturbance. The state-and-transition model for the Patagonian steppes. Ecología Austral 8:191-199.

Bestelmeyer, B. T., J. R. Brown, K. M. Havstad, R. Alexander, G. Chavez, and J. E. HeRRICK. 2003. Development and use of state-and-transition models for rangelands. Journal of Range Management 56:114-126.

Blake, G. R. 1982. Core method. In: Black, C. A., D. D. Evans, J. L. White, L. E. Ensminger, and F. E. Clarck [EDS.]. Methods of Soil Analysis-Physical and Mineralogical Properties, Including Statistics of Measurement and Sampling. Serie Agronomy No. 9. Wisconsin, USA: American Society of Agronomy. p 374-390.

Briske, D. D., S. D. Fuhlendorf, And F. E. Smeins. 2005. State-and-transition models, thresholds, and rangeland health: a synthesis of ecological concepts and perspectives. Rangeland Ecology \& Management 58:1-10.
Carter, M. R. 2002. Soil quality for sustainable land management: organic matter and aggregation interactions that maintain soil functions. Agronomy Journal 94:38-47.

Davenport, D. W., D. D. Breshears, B. P. Wicox, and C. D. Allen. 1998. Viewpoint: sustainability of piñon-juniper ecosystems - a unifying perspective of soil erosion threshold. Journal of Range Management 51:231-240.

de Soyza, A. G., J. W. Van Zee, W. G. Whitford, A. Neale, N. Tallent-Hallsel, J. E. Herrick, and K. M. Havstad. 2000. Indicators of Great Basin rangeland health. Journal of Arid Environments 45:289-304.

Didham, R. K., AND C. H. WATTS. 2005. Are systems with strong underlying abiotic regimes more likely to exhibit alternative stable states? Oikos 110:409-416.

Elissalde, N., J. M. Escobar, and V. Nakamatsu. 2002. Inventario y evaluación de pastizales naturales de la zona árida y semiárida de la Patagonia. Programa de Acción Nacional de Lucha contra la Desertificación, SDSyPA-INTA-GTZ. Trelew, Chubut, Argentina. 45 p.

FrIEDEL, M. H. 1991. Range condition assessment and the concept of thresholds: a viewpoint. Journal of Range Management 44:422-426.

Gile, L. H., and R. B. Grossman. 1979. The Desert Project soil monograph. Washington, DC: Soil Conservation Service, USDA. 984 p.

GoodALL, D. W. 1952. Some considerations in the use of point quadrats for the analysis of vegetation. Australian Journal of Science. Series B 5:1-41.

Havstad, K. M., and J. E. HerRick. 2003. Long-term ecological monitoring. Arid Land Research and Management 17:389-400.

Hudson, B. D. 1994. Soil organic matter and available water capacity. Journal of Soil and Water Conservation 49:189-194.

Kettler, T. A., J. W. Doran, and T. L. Gilbert. 2001. Simplified method for soil particle-size determination to accompany soil-quality analyses. Soil Science Society of America Journal 65:849-852.

LAL, R. 1988. Monitoring soil erosion's impact on crop productivity. In: R. Lal [ED.]. Soil erosion research methods. Ankeny, IA: Soil and Water Conservation Society. p 187-200.

LAYcoCk, W. A. 1991. Stable states and thresholds of range condition on North American rangelands: a viewpoint. Journal of Range Management 44: 427-433.

LAYcoCk, W. A. 1995. New perspectives on ecological condition of rangeland: can state-and-transition or other models better define condition and diversity? In: Montes, L., and G. Oliva. [EDS.]. Actas del Taller Internacional sobre Recursos Filogenéticos, Desertificación y Uso Sustentable. Río Gallegos, Argentina. p 36-45.

Le Houérou, H. N. 1991. An overview of vegetation and land degradation in world arid lands. In: H. Dregne [ED.]. Degradation and Restoration of Arid Lands. Lubbock, TX: ICASALS, Texas Tech University. p 127-164.

Mutchler, C. K., C. E. Murphree, And K. C. McGregor. 1988. Laboratory and field plots for soil erosion studies. In: R. Lal [ED.] Soil Erosion Research Methods. Ankeny, IA: Soil and Water Conservation Society. p 9-39.

nRC (National Research Council). 1994. Rangeland health: new methods to classify, inventory, and monitor rangelands. Washington, DC: National Academy Press. 180 p.

Parizek, B., C. M. Rostagno, and R. Sottini. 2002. Soil erosion as affected by shrub encroachment in northeastern Patagonia. Journal Range Management 55: 43-48.

PIckUP, G. 1985. The erosion cell-a geomorphic approach to landscape classification in range assessment. The Australian Rangeland Journal 7: 114-121.

Pierson, F. B., W. H. Blackburn, S. S. Van Vactor, and J. C. Wood. 1994. Partitioning small scale spatial variability of runoff and erosion on sagebrush rangelands. Water Resources Bulletin 30:1081-1089.

Poesen, J. W., D. Torri, and K. Bunte. 1994. Effects of rock fragments on soil erosion by water at different spatial scales: a review. Catena 23:141-166.

Rostagno, C. M. 1989. Infiltration and sediment production as affected by soil surface conditions in a shrubland of Patagonia, Argentina. Journal of Range Management 42:382-385.

Rostagno, C. M., M. P. Chartier, and A. Toyos. 2004. Las plantas descalzas como indicadores de la tasa de erosión de los suelos. [Resumen de Congreso] II Reunión Binacional de Ecología, Mendoza, Argentina. p 275. 
Rostagno, C. M., and H. F. del Valle. 1988. Mounds associated with shrubs in aridic soils of northeastern Patagonia: characteristics and probable genesis. Catena 15:347-359.

Rostagno, C. M., H. F. del Valle, and L. Videla. 1991. The influence of shrubs on some chemical and physical properties of an aridic soil in northeastern Patagonia, Argentina. Journal of Arid Environments 20:179-188.

Rostagno, C. M., and D. Garayzar. 1995. Diseño de un simulador de lluvia para estudios de infiltración y erosión de suelos. Ciencia del Suelo 13: $41-43$.

Scheffer, M., S. Carpenter, J. A. Foley, C. Folke, and B. Walker. 2001. Catastrophic shifts in ecosystems. Nature 413:591-596.

Schlesinger, W. H., J. F. Reynolds, G. L. Cunningham, L. F. Huennke, W. M. Jarrell, R. A. VIRGiniA, AND W. G. Whitford. 1990. Biological feedbacks in global desertification. Science 247:1043-1048.

Simanton, J. R, M. A. Weltz, and H. D. Larsen. 1991. Rangeland experiments to parameterize the water erosion prediction project model: vegetation canopy cover effects. Journal of Range Management 44:276-282.

SRM TASK Group (Society for Range Management Task Group on Unity in Concepts and Terminology Committee, Society for Range Management). 1995. New concepts for assessment of rangeland condition. Journal of Range Management 48:271-282.

Stringham, T. K., W. C. Krueger, and P. L. Shaver. 2003. State and transition modeling: an ecological process approach. Journal of Range Management $56: 106-113$

Suding, K. N., K. L. Gross, and G. R. Houseman. 2004. Alternative states and positive feedbacks in restoration ecology. Trends in Ecology and Evolution 19: 46-53.
Súnico, A., P. Bouza, and H. del Valle. 1996. Erosion of subsurface horizons in northeastern Patagonia, Argentina. Arid Soil Research and Rehabilitation 10:359-378.

TongwaY, D. J., AND J. A. LudWIG. 1996. The nature of landscape dysfunction in rangelands. In: J. Ludwig, D. Tongway, D. Freudenberger, J. Noble, and K. Hudgkinson [EDS.]. Landscape Ecology. Function and Management. Principles from Australia's Rangelands. CSIR0, Australia. p 49-61.

van de Koppel, J., M. Rietkerk, F. van Langevelde, L. Kumar, C. A. Klausmeier, J. M. Fryxell, J. W. Hearne, J. van Andel, N. de Ridder, A. Skidmore, L. Stroosnidder, AND H. H. T. PRINS. 2002. Spatial heterogeneity and irreversible vegetation change in semiarid grazing systems. American Naturalist 159:209-218.

van de Koppel, J., M. RietkeRK, And F. J. Weissing. 1997. Catastrophic vegetation shifts and soil degradation in terrestrial grazing systems. Trends in Ecology and Evolution 12:352-356.

Vicenty, O. A., J. J. SerRa, and A. D. Gabetta. 1984. Estudio de las precipitaciones en la ciudad de Trelew, Chubut. Ministerio de Economía y Servicios de Obras Públicas. Rawson, Chubut, Argentina. $44 \mathrm{p}$.

Watters, S. A., M. A. Weltz, and E. L. Smith. 1996. Evaluation of a site conservation rating system in southeastern Arizona. Journal Range Management 49: 277-284.

Weltz, M. A., M. Kidwell, and H. Dale Fox. 1998. Influence of abiotic and biotic factors in measuring and modeling soil erosion on rangelands: State of knowledge. Journal Range Management 51:482-495.

Westoby, M., B. WalkeR, and I. Noy-Meir. 1989. Opportunistic management for rangelands not at equilibrium. Journal Range Management 42:266-274.

WhISENANT, S. G. 1999. Repairing damaged wildlands: a process-oriented, landscape-scale approach. New York, NY: Cambridge University Press. 312 p. 